\title{
Role of Expression of Inflammatory Mediators in Primary and Recurrent Lumbar Disc Herniation
}

\author{
Yasar Dagistan, M.D., ${ }^{1}$ Selma Cukur, M.D., ${ }^{2}$ Emine Dagistan, M.D., ${ }^{3}$ Ali Riza Gezici, M.D. \\ Department of Neurosurgery, Pathology, Radiology, Abant Izzet Baysal University Medical School, Izzet Baysal Training and Research \\ Hospital, Bolu, Turkey
}

Objective: To assess role of some inflammatory mediators in patients with primary and recurrent lumbar disc herniation. Expression of IL-6, transforming growth factor (TGF)-1, insulin-like growth factor (IGF)-1, and Bcl-2-associated X protein (BAX) have been shown to be more intense in the primary group than the recurrent goup, but this mediators may be important aspects prognostic.

Methods: 19 patients underwent primary and revision operations between June 1, 2009 and June 1, 2014, and they were included in this study. The 19 patients' intervertebral disc specimens obtained from the primary procedures and reoperations were evaluated. Expression of IL-6, TGF-1, IGF-1, and BAX were examined immunohistochemically in the 38 biopsy tissues obtained from the primary and recurrent herniated intervertebral discs during the operation.

Results: For IL-6 expression in the intervertebral disc specimens, there was no difference between the groups. The immunohistochemical study showed that the intervertebral disc specimens in the primary group were stained intensely by TGF1 compared with the recurrent group. Expression of IGF-1 in the primary group was found moderate. In contrast, in the recurrent group of patients was mild expression of IGF-1. The primary group intervertebral disc specimens were stained moderately by BAX compared with the recurrent group.

Conclusion: The results of our prognostic evaluation of patients in the recurrent group who were operated due to disc herniation suggest that mediators may be important parameters.

Key Words : Inflammatory mediators · Disc herniation · Immunohistochemical.

\section{INTRODUCTION}

Lumbar disc herniation (LDH) is the most frequent disorder of the lumbar spine, and it is treated surgically at times ${ }^{5}$. However, in $15-30 \%$ of cases, discectomy-related complications occur, such as hemorrhage, soft-tissue infection, nerve root injury, dural tear, recurrent or residual disc herniation, epidural scar formation, discitis, arachnoiditis, pseudomeningocele, facet joint fracture (iatrogenic or stress related), spinal stenosis, and epidural hematoma ${ }^{3,28)}$. The total failure rate after discectomy is $3-20 \%{ }^{6,17,28)}$. Additionally, the recurrence rate at the same level regardless of ipsilateral or contra-

- Received: November 12, 2015 • Revised: June 8, 2016 •Accepted: June 21, 2016

- Address for reprints : Yasar Dagistan, M.D.

Department of Neurosurgery, Abant Izzet Baysal University Medical School, 14280 Gölköy, Bolu, Turkey

Tel : +90-374-2534656-3280, Fax : +90-374-2534615, E-mail : dagistanyasar@hotmail.com

This is an Open Access article distributed under the terms of the Creative Commons Attribution Non-Commercial License (http://creativecommons.org/licenses/by-nc/4.0) which permits unrestricted non-commercial use, distribution, and reproduction in any medium, provided the original work is properly cited. 
lateral herniation has been reported to be $5-11 \% .^{6,718,28)}$. Reherniation has been suggested to be the most common cause of lumbar disc reoperation ${ }^{1,17)}$. The risk of adverse outcomes such as obesity, diabetes, vibration works, drivers, and psychological factors, which increase the incidence of recurrence, should be considered before surgery ${ }^{11)}$. Elevated levels of molecular mediators of inflammation have been reported in pathologic disc tissue, with their quantities increasing with the extent of degeneration ${ }^{16,35)}$. The aim of the present study was to assess role of inflammatory mediators such as IL-6, transforming growth factor (TGF)-1, insulin-like growth factor (IGF)-1, and Bcl-2-associated X protein (BAX) in patients with primary and recurrent lumbar disc herniation.

\section{MATERIALS AND METHODS}

The procedure adopted herein was approved by the Ethics Committee of Abant Izzet Baysal University. Among 500 patients treated surgically for LDH in our department, 19 patients underwent primary and revision operations between June 1, 2009 and June 1, 2014, and they were included in this study. The 19 patients' intervertebral disc specimens obtained from the primary procedures and reoperations were evaluated. Ten of the patients were men, and nine were women. Informed consent for specimen collection was obtained from all patients. The levels involved were L4 -5 (12 patients), L5-S1 (6 patients), and L3-4 (1 patients). Disc herniation was assessed by computed tomography (CT)/magnetic resonance imaging (MRI) and confirmed using operative findings. Disc materials were collected by both microsquestrectomy and discectomy from disc space through annulus. Expression of IL-6, TGF-1, IGF-1, and BAX were examined immunohistochemically in the 38 biopsy tissues obtained from the primary and recurrent herniated intervertebral discs during the operation and embedded in paraffin.

\section{Immunohistochemistry}

The tissues were fixed in Bouin's solution and embedded in paraffin. Sections of 4- $\mu \mathrm{m}$ thickness were cut, dewaxed in xylene, and incubated for $20 \mathrm{~min}$ in $0.3 \% \mathrm{H}_{2} \mathrm{O}_{2}$ to block endogenous peroxidase activity. Then, the sections were processed following the standard avidin-biotin peroxidase complex procedure. Nonspecific binding was blocked with 3\% normal goat serum in a phosphate buffered saline (PBS) solution $\mathrm{pH} 7.4$ for $30 \mathrm{~min}$ at room temperature. The slides were then incubated overnight with primary antibodies at $4^{\circ} \mathrm{C}$. The following antibodies were used: polyclonal mouse antiIGF-1 (GeneTex Inc., Irvine, CA, USA, 1:100), polyclonal rabbit anti-IL-6 (GeneTex, 1:00), polyclonal rabbit anti-TGF-1 (GeneTex, 1:25), and monoclonal rabbit Bax (GeneTex, 1:250). Rabbit and mouse immunoglobulins of the same dilutions as primary antibodies were used as controls. Peroxidase activity was revealed by incubation in $0.05 \% 3,3$ 'diaminobenzidine tetrahydrochloride in PBS containing $0.03 \%$ peroxide for 5 min at room temperature; the slides were then washed, dehydrated, and mounted with Entellan (Merck KGaA, Darmstadt, Germany). The experiments were reproduced in triplicate, and the slides were examined under a Nikon E600 light microscope by two experienced observers blinded to each other and to the harvested tissues. The immunostaining intensity was evaluated by considering the reactive cells or fibers in 20 random fields per slide (lens: 20). The immunuhistochemical expressions were evaluated in three categories: mild (value $=1$ ), moderate (value $=2$ ), and intense (value $=3$ ).

\section{Statistical analysis}

SPSS 11.0 software (SPSS Inc., Chicago, IL, USA) for Windows was used for statistical analyses. Data are expressed as mean SD and analyzed for statistical significance using oneway analysis of variance (ANOVA), followed by the post-hoc Tukey test. Differences between the mean values were considered significant when $p<0.05$.

\section{RESULTS}

We included 19 patients to the study. The mean age of the patients was 39.5 years (6.4 SD). The results of IL-6, TGF-1, 
IGF-1, and BAX expressions examined immunohistochemically using the biopsy tissues taken from the intervertebral discs of patients of primary and recurrent lumbar disc herniation are summarized in Table 1.

Clinical data of the patients before and after surgery sum-

Table 1. Expression of IL-6, TGF-1, IGF-1, and BAX examined immunohistochemically using biopsy tissues taken from primary and recurrent disc hernia patients.

\begin{tabular}{lcccc}
\hline Groups & IL-6 & TGF & IGF- 1 & BAX \\
\hline Primary $(n=19)$ & $1.9 \pm 0.6$ & $2.6 \pm 0.5^{*}$ & $1.9 \pm 0.7^{\dagger}$ & $1.5 \pm 0.5^{\ddagger}$ \\
Recurrent $(n=19)$ & $1.4 \pm 0.6$ & $1.8 \pm 0.7$ & $1.4 \pm 0.6$ & $1.1 \pm 0.3$ \\
\hline
\end{tabular}

Values expressed as meanstandard deviation. ${ }^{*} p<0.003$ compared with recurrent group. ${ }^{\dagger} p<0.05$ compared with recurrent group. ${ }^{\neq} p<0.05$ compared with recurrent group. IL-6 : interleukin 6, TGF-1 : transforming growth factor-1, IGF-1 : insulin-like growth factor-1, BAX : Bcl-2associated $X$ protein

Table 2. Clinical data of the patients before and after surgery

\begin{tabular}{lcc}
\hline & Before surgery $(\mathbf{n})$ & After surgery $(\mathbf{n})$ \\
\hline Back pain & 19 & 0 \\
Leg pain & 19 & 0 \\
Leg numbness & 19 & 1 \\
motor lost & 3 & 1 \\
Reflex loss & 8 & 2 \\
Sexual dysfunction & 1 & 1 \\
Urinary incontinence & 1 & 1 \\
\hline
\end{tabular}

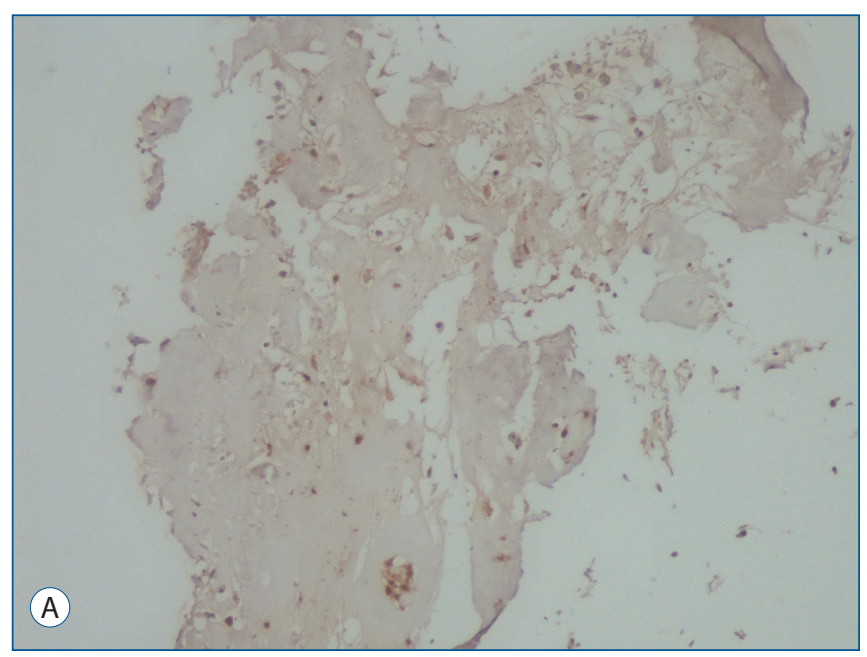

marized in Table 2.

IL-6 expression in the intervertebral disc specimens of the primary group was stained moderately (Fig. 1A). IL-6 expression in the intervertebral disc specimens was mild in the recurrent group when compared with that in primary group. However, there was no difference between the groups (Fig. 1B).

The immunohistochemical study showed that the intervertebral disc specimens in the primary group were stained intensely by TGF-1 compared with the recurrent group $(\mathrm{p}<0.003)$ (Fig. 2A, B).

Fig. 3A shows moderate expression of IGF-1 in the primary group. In contrast, Fig. 3B shows mild IGF-1 expression in the intervertebral disc tissue from the recurrent group of patients $(p<0.05)$.

The primary group intervertebral disc specimens were stained moderately by BAX compared with the recurrent group $(p<0.05)$ (Fig. 4A, B).

\section{DISCUSSION}

Despite the development of modern and microsurgery techniques and the reporting of successful results in lumbar disc surgery, more than $10 \%$ of patients suffer from long-

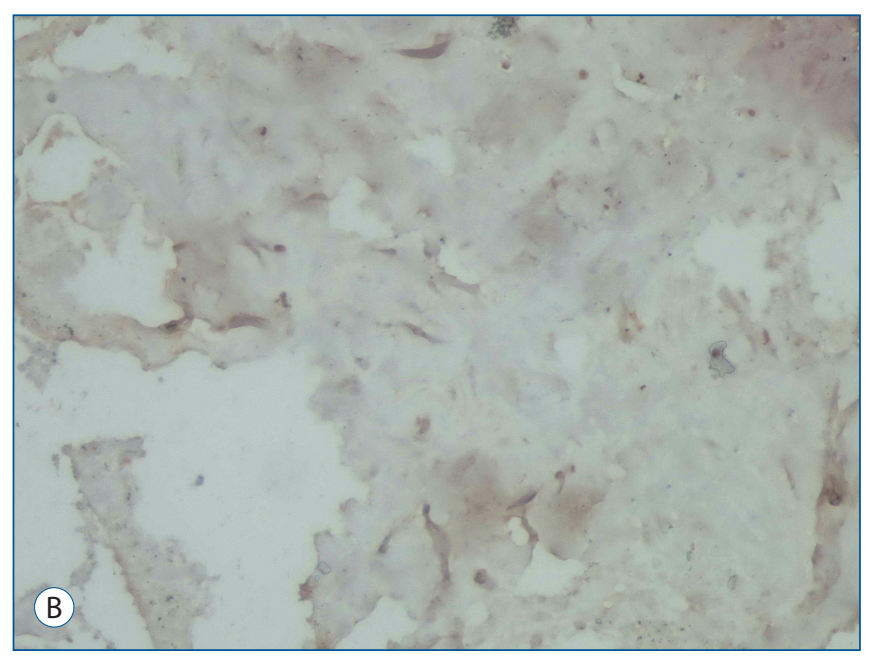

Fig. 1. Immunohistochemical staining of intervertebral disc for IL-6 expression. A : IL-6 expression in chondrocytes of the intervertebral disc was moderate in the primary group (Immun-Peroxidase, original magnification 100). B:In the recurrent group, in chondrocytes of the intervertebral disc were stained mild by IL-6 (Immuno-Peroxidase, original magnification 100). 

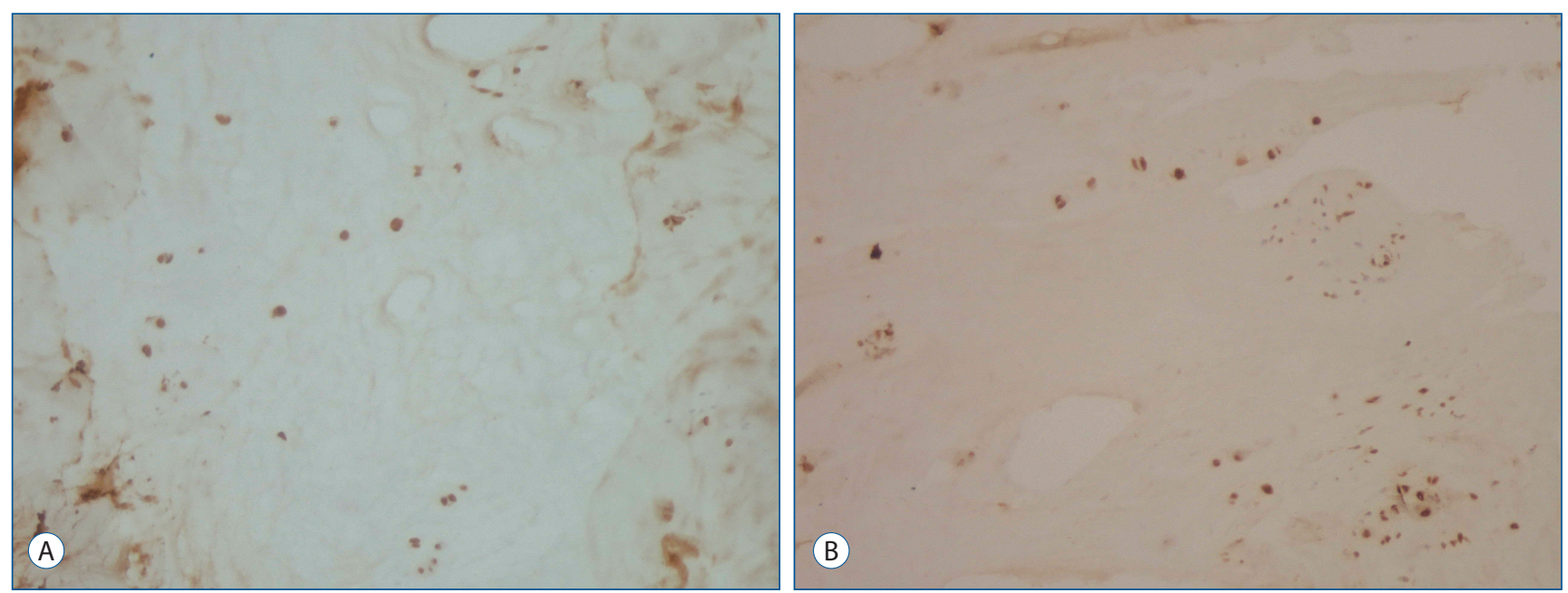

Fig. 2. Immunohistochemical staining of the intervertebral disc for TGF. A : The chondrocytes of the intervertebral disc in primary group were stained intensely by TGF (Immun-Peroxidase, original magnification 100). B : In contrast, the chondrocytes of the intervertebral disc in the recurrent group were stained moderate by TGF (Immuno-Peroxidase, original magnification 100). TGF : transforming growth factor.
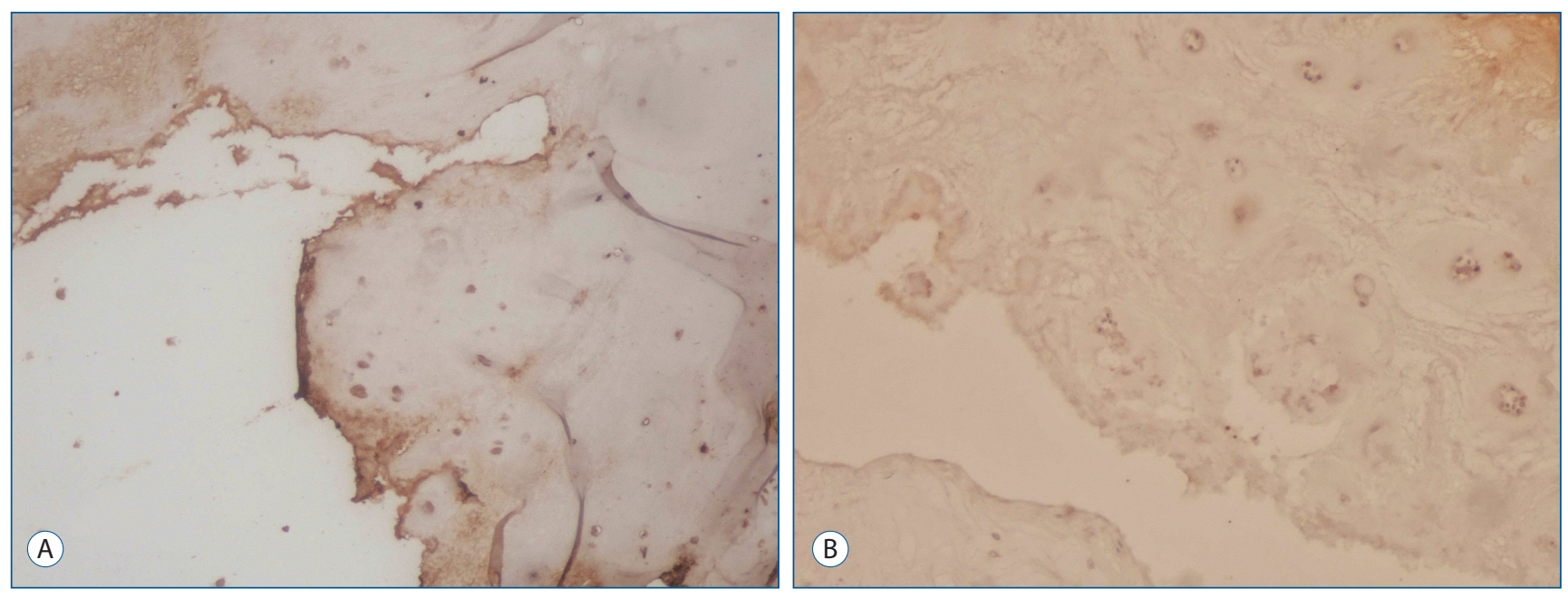

Fig. 3. Immunohistochemical staining of the intervertebral disc for IGF-1 expression. A : An IGF-1 expression was moderate in the primary group (Immuno-Peroxidase, original magnification 100). B : In the recurrent group, the chondrocytes in the intervertebral disc were stained mild by IGF-1 (Immun- Peroxidase, original magnification 100). IGF-1 : insulin-like growth factor-1.

term recurrent pain, which increases healthcare costs ${ }^{2)}$. The precise mechanism of recurrent lumbar disc herniation remains unclear ${ }^{36}$. The causes and characteristics of reoperations after different primary surgeries have been not specified in the population-based data.

In recent clinical studies, elevated levels of proinflammatory cytokines (IFN-c, IL-1b, IL-2, IL-6, and TNF-a) correlated with elevated pain scores in various types of neurological and rheumatologic disorders ${ }^{20,31,33}$. While IL-6 production occurs in various cell types, Takada et al. ${ }^{29)}$ showed that mac- rophages are the major cells in disc herniation-associated pathology. IL-6 helps mediate the acutephase response to injury, promote monocyte differentiation into macrophages, and activate maturation of both B- and T-lineage lymphocytes. Burke et al. ${ }^{4)}$ found significantly higher levels of IL-6 and IL-8 in discs from low back-pain patients compared those in to discs from sciatica patients, independent of the presence of an intact anulus fibrosus or nuclear extrusions. TGF- $\beta 1$ is known to be involved the repair process of connective tissue and to induce the formation of inflammatory 

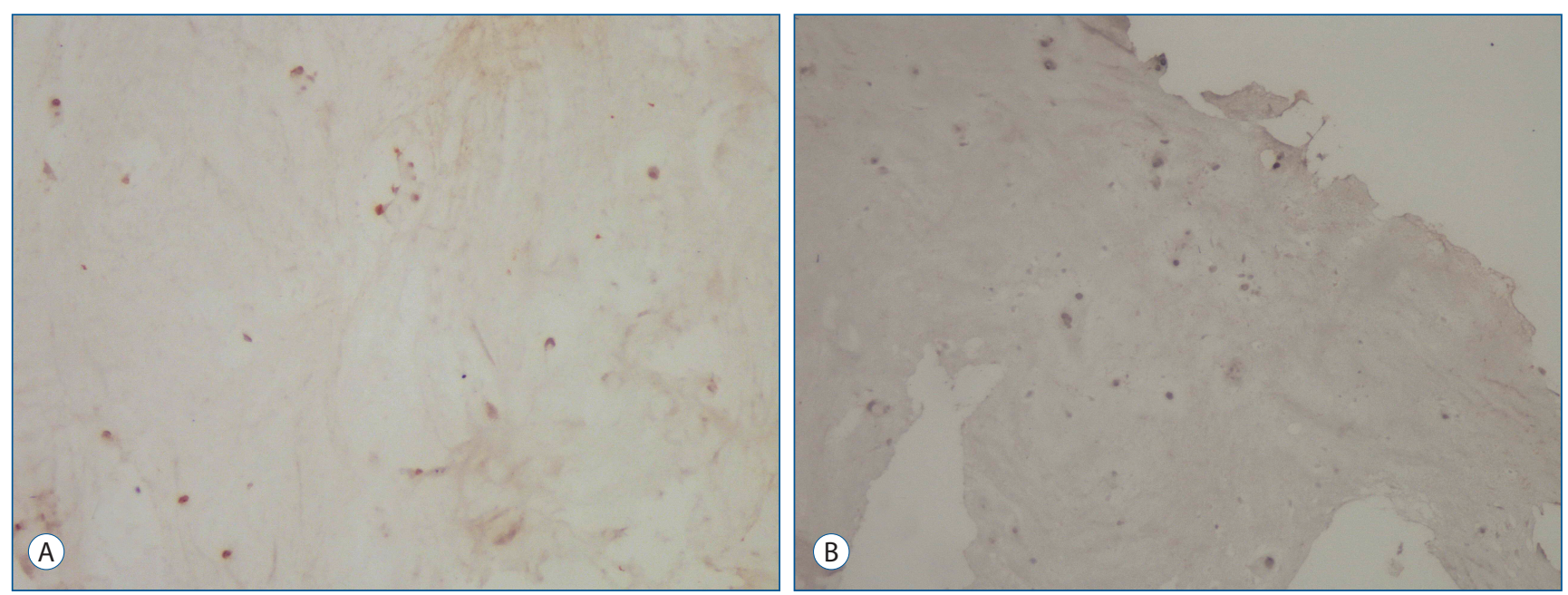

Fig. 4. Immunohistochemical staining of the intervertebral disc for BAX. A : The chondrocytes of the intervertebral disc in primary group were stained moderately by BAX (Immun-Peroxidase, original magnification 100). B : In contrast, the chondrocytes of the intervertebral disc in the recurrent group were stained mild by BAX (Immuno-Peroxidase, original magnification 100). BAX : Bcl-2-associated X protein.

and granulation tissues ${ }^{15)}$. The role of TGF- $\beta 1$ in repair is directed toward several cell types such as fibroblasts, monocytes, and endothelial cells ${ }^{15)}$. TGF- $\beta 1$ improves the synthesis of collagens and fibronectin, and the arrangement of the extracellular matrix ${ }^{25}$. Moreover, TGF- $\beta 1$ is a chemoattractant for fibroblasts and monocytes and may hence induce the movement of cells to repair-needing areas ${ }^{24)}$. Additionally, the use of TGF- $\beta$ on hernia disc cells causes an anabolic response, characterized by increased proteoglycan synthesis and decreased tissue resorption via decreased MMP-2 secre$\operatorname{tion}^{8,22)}$. In addition, a transient proliferative effect was observed on cultivated disc cells ${ }^{8)}$.

IGF-1 increases proteoglycan synthesis in the nucleus pulposus and stimulates the growth of bone and cartilage; then, the increased IGF-1 expression works toward repairing the extruded disc material ${ }^{30,27}$. IGF-1 is produced predominantly in the liver in response to the action of growth hormone and is transferred into the serum, which is a key anabolic factor in the growth and differentiation of normal cartilage tissue ${ }^{23,26)}$. In a previous study, local release of IGF-1 was detected in the intervertebral disc: the expression of IGF1 mRNA and IGF-1-receptor in disc tissue was greater in cells of the nucleus pulposus of fetal bovine intervertebral discs than in those of the adult disc ${ }^{21)}$. Jennische et al. ${ }^{10)}$ suggest that the production of IGF-1 during tissue repair in adult herniated intervertebral discs might represent an attempt to repair the matrix.

BAX (Bcl-2-associated X protein) is required for the release of cytochrome $\mathrm{c}$, a critical factor in the initiation of cell death pathways derived from the mitochondrion ${ }^{14,32,34)}$. It has been suggested that the downregulation of key apoptosis-regulating proteins such as Bcl-2 promotes mitochondrial membrane permeability, which subsequently leads to activation of the intrinsic caspase-dependent pathway via caspase-9 and, finally, caspase-3/7-mediated apoptosis ${ }^{9,12,19)}$. In addition, studies have demonstrated that the down regulation of collagen type II is closely related to a substantial reduction in the level of Bcl-2 protein $^{13)}$.

We shall discuss the reasons why inflammatory cytokines in second intervention were not as high as in those first surgical procedure. The initial pathological process of disc hernia is associated with greater burden of inflammation. Symptoms of the patients with hernia recurrence was mostly a consequence of anatomical changes (e.g. discontinuation of posterior ligament structure) rather than inflammation.

In this study, for the first time, some mediators in the same patient group with primary and recurrent hernia were investigated. Tissue levels of mediators were found to be decreased in the relapse. Decrease in TGF-1, IGF, and Bax levels were statistically significant. The presence of higher levels of me- 
diators in the primary group shows that there is greater activity in these patients. Additionally, the mediators investigated in the present study are considered to be effective at lower activity levels in cases of recurrence in correlation with an inflammatory process than in patients in the primary group. The results of our prognostic evaluation of patients in the recurrent group who were operated due to disc herniation suggest that mediators may be important parameters.

\section{References}

1. Aizawa T, Ozawa H, Kusakabe T, Nakamura T, Sekiguchi A, Takahashi $A$, et al. : Reoperation for recurrent lumbar disc herniation: a study over a 20-year period in a Japanese population. J Orthop Sci 17 : 107-113, 2012

2. Ambrossi GLG, McGirt MJ, Sciubba DM, Witham TF, Wolinsky JP, Gokaslan ZL, et al. : Recurrent lumbar disc herniation after single-level lumbar discectomy: incidence and health care cost analysis. Neurosurgery 65 : 574-578; discussion 578, 2009

3. Babar S, Saifuddin A : MRI of the post-discectomy lumbar spine. Clin Radiol 57 : 969-981, 2002

4. Burke JG, Watson RWG, McCormack D, Dowling FE, Walsh MG, Fitzpatrick JM : Intervertebral discs which cause low back pain secrete high levels of proinflammatory mediators. J Bone Joint Surg Br 84 : 196201, 2002

5. Cheng JW, Wang HW, Zheng WJ, Li CQ, Wang J, Zhang ZF, et al. : Reoperation after lumbar disc surgery in two hundred and seven patients. Int Orthop 37 : 1511-1517, 2013

6. Fandino J, Botana C, Viladrich A, Gomezbueno J : Reoperation after lumbar disc surgery - results in 130 cases. Acta Neurochir (Wien) 122 : 102-104, 1993

7. Gibson JNA, Waddell $\mathrm{G}$ : Surgical interventions for lumbar disc prolapse - updated cochrane review. Spine 32 : 1735-1747, 2007

8. Gruber HE, Fisher EC Jr, Desai B, Stasky AA, Hoelscher G, Hanley EN Jr : Human intervertebral disc cells from the annulus: three-dimensional culture in agarose or alginate and responsiveness to TGF-beta 1. Exp Cell Res 235 : 13-21, 1997

9. Heyde CE, Tschoeke SK, Hellmuth M, Hostmann A, Ertel W, Oberholzer A : Trauma induces apoptosis in human thoracolumbar intervertebral discs. BMC Clin Pathol 6 : 5, 2006

10. Jennische $E$, Skottner $A$, Hansson $H A$ : Dynamic changes in insulin-like growth factor I immunoreactivity correlate to repair events in rat ear after freeze-thaw injury. Exp Mol Pathol 47 : 193-201, 1987

11. Kara B, Tulum Z, Acar U : Functional results and the risk factors of reoperations after lumbar disc surgery. Eur Spine J 14 : 43-48, 2005
12. Kiechle FL, Zhang XB : Apoptosis: biochemical aspects and clinical implications. Clin Chim Acta 326 : 27-45, 2002

13. Kinkel MD, Horton WE Jr : Coordinate down-regulation of cartilage matrix gene expression in $\mathrm{Bcl}-2$ deficient chondrocytes is associated with decreased SOX9 expression and decreased mRNA stability. J Cell Biochem 88 : 941-953, 2003

14. Korsmeyer SJ, Wei MC, Saito M, Weller S, Oh KJ, Schlesinger PH : Proapoptotic cascade activates BID, which oligomerizes BAK or BAX into pores that result in the release of cytochrome c. Cell Death Differ 7 : 1166-1173, 2000

15. Laiho M, Keski-Oja J : Growth factors in the regulation of pericellular proteolysis: a review. Cancer Res 49 : 2533-2553, 1989

16. Le Maitre $\mathrm{CL}$, Hoyland JA, Freemont AJ : Catabolic cytokine expression in degenerate and herniated human intervertebral discs: IL-1beta and TNFalpha expression profile. Arthritis Res Ther 9 : R77, 2007

17. Matsumoto M, Watanabe K, Hosogane N, Tsuji T, Ishii K, Nakamura M, et al. : Recurrence of Lumbar Disc Herniation after Microendoscopic Discectomy. J Neurol Surg A Cent Eur Neurosurg 74 : 222-227, 2013

18. Morgan-Hough CV, Jones PW, Eisenstein SM : Primary and revision lumbar discectomy - a 16-year review from one centre. J Bone Joint Surg $\mathrm{Br} 85$ : 871-874, 2003

19. Oberholzer C, Oberholzer A, Clare-Salzler M, Moldawer LL : Apoptosis in sepsis: a new target for therapeutic exploration. FASEB J 15 : 879-892, 2001

20. Ohtori S, Suzuki M, Koshi T, Takaso M, Yamashita M, Inoue G, et al. : Proinflammatory cytokines in the cerebrospinal fluid of patients with lumbar radiculopathy. Eur Spine J 20 : 942-946, 2011

21. Osada R, Ohshima $H$, Ishihara $H$, Yudoh $K$, Sakai $K$, Matsui $H$, et al. : Autocrine/paracrine mechanism of insulin-like growth factor-1 secretion, and the effect of insulin-like growth factor-1 on proteoglycan synthesis in bovine intervertebral discs. J Orthop Res 14 : 690-699, 1996

22. Pattison ST, Melrose J, Ghosh P, Taylor TK : Regulation of gelatinase-A (MMP-2) production by ovine intervertebral disc nucleus pulposus cells grown in alginate bead culture by transforming growth factor-beta(1) and insulin like growth factor-I. Cell Biol Int 25 : 679-689, 2001

23. Phillip M, Maor G, Assa S, Silbergeld A, Segev $Y$ : Testosterone stimulates growth of tibial epiphyseal growth plate and insulin-like growth factor-1 receptor abundance in hypophysectomized and castrated rats. Endocrine 16 : 1-6, 2001

24. Postlethwaite $A E$, Keskioja J, Moses $\mathrm{HL}$, Kang AH : Stimulation of the chemotactic migration of human fibroblasts by transforming growth factor beta. J Exp Med 165 : 251-256, 1987

25. Roberts AB, Sporn MB, Assoian RK, Smith JM, Roche NS, Wakefield LM, et al. : Transforming growth factor type beta: rapid induction of fibrosis and angiogenesis in vivo and stimulation of collagen formation in vitro. Proc Natl Acad Sci U S A 83 : 4167-4171, 1986

26. Schwander JC, Hauri C, Zapf J, Froesch ER : Synthesis and secretion of insulin-like growth factor and its binding protein by the perfused rat liver: dependence on growth hormone status. Endocrinology 113 : 
297-305, 1983

27. Specchia N, Pagnotta A, Toesca A, Greco F : Cytokines and growth factors in the protruded intervertebral disc of the lumbar spine. Eur Spine J 11 : 145-151, 2002

28. Suk KS, Lee HM, Moon SH, Kim NH : Recurrent lumbar disc herniation: results of operative management. Spine (Phila Pa 1976) 26 : 672676, 2001

29. Takada T, Nishida K, Doita M, Miyamoto H, Kurosaka M : Interleukin-6 production is upregulated by interaction between disc tissue and macrophages. Spine (Phila Pa 1976) 29 : 1089-1092; discussion 1093, 2004

30. Thompson JP, Oegema TR Jr, Bradford DS : Stimulation of mature canine intervertebral-disk by growth-factors. Spine (Phila Pa 1976) 16 : 253260, 1991

31. Uceyler N, Kafke W, Riediger N, He L, Necula G, Toyka KV, et al. : Elevated proinflammatory cytokine expression in affected skin in small fiber neuropathy. Neurology 74 : 1806-1813, 2010

32. von Ahsen O, Renken C, Perkins G, Kluck RM, Bossy-Wetzel E, New- meyer DD : Preservation of mitochondrial structure and function after Bid- or Bax-mediated cytochrome c release. J Cell Biol 150 : 10271036, 2000.

33. Wang HL, Ahrens C, Rief W, Gantz S, Schiltenwolf M, Richter W : Influence of depression symptoms on serum tumor necrosis factor-alpha of patients with chronic low back pain. Arthritis Res Ther 12 : R186, 2010

34. Wei MC, Zong WX, Cheng EH, Lindsten T, Panoutsakopoulou V, Ross $A J$, et al. : Proapoptotic BAX and BAK: a requisite gateway to mitochondrial dysfunction and death. Science 292 : 727-730, 2001

35. Weiler C, Nerlich AG, Bachmeier BE, Boos N : Expression and distribution of tumor necrosis factor alpha in human lumbar intervertebral discs: a study in surgical specimen and autopsy controls. Spine (Phila Pa 1976) $30: 44-53,2005$

36. Wera GD, Marcus RE, Ghanayem AJ, Bohlman HH : Failure within one year following subtotal lumbar discectomy. J Bone Joint Surg Am 90 : $10-15,2008$ 